DOI: https://doi.org/10.31933/dijemss.v2i4

Received: $30^{\text {th }}$ March 2021, Revised: $15^{\text {th }}$ April 2021, Publish: $25^{\text {th }}$ April 2021

\begin{tabular}{|c|c|c|}
\hline PINASTIST & $\begin{array}{l}\text { DIJEMSS } \\
\text { DINASTI INTERNATIONAL JOURNAL } \\
\text { OF EDUCATION MANAGEMENT AND } \\
\text { SOCIAL SCIENCE }\end{array}$ & $\begin{array}{r}\text { https://dinastipub.org/DIJEMSS } \\
\text { editor@dinastipub.org } \\
08117401455\end{array}$ \\
\hline
\end{tabular}

\title{
SELF EFFICACY MODEL AND CAREER DEVELOPMENT IN INCREASE EMPLOYEE ENGAGEMENT AND NURSE PERFORMANCE
}

\author{
Gede Pronajaya $^{1}$ Rina Anindita ${ }^{2}$ Rian Adi Pamungkas ${ }^{3}$ \\ ${ }^{1)}$ Faculty of Health Sciences, Esa Unggul University Jakarta, nersgede18@ gmail.com \\ ${ }^{2)}$ Faculty of Health Sciences, Esa Unggul University Jakarta \\ ${ }^{3)}$ Faculty of Health Sciences, Esa Unggul University Jakarta
}

\section{Corrresponding Author: First Author}

\begin{abstract}
One of the factors for the success of human resource management in an organization is employee performance. Organizations can be said to be successful when the performance of the organization's employees is good. The results of nursing audits are still low in one room, namely below $90 \%$, the high rate of turnover that occurs in nurses every year, the influence of self-efficacy on the performance of nurses, and the level of clinical nurse IV are still small. The purpose of this study was to determine and analyze the effect of Self Efficacy and Career Development on Employee Engagement and Nurse Performance at Dharmais Cancer Hospital. The research sample consisted of 200 respondents. The design of this research is explanatory research of causality (explanatory research). The data analysis technique used the Three-Box Method and SEM (Structural Equation Model) with the AMOS 24 program. The results showed that selfefficacy and career development indirectly mediated by employee engagement had not affected nurse performance; employee engagement does not affect nurse performance; self-efficacy has a positive effect on nurse performance; career development does not affect nurse performance; Self-efficacy has a positive effect on employee engagement; Career development does not affect employee engagement. Research findings: nurse performance in the high category, self-efficacy in the high category, career development in the good category, and employee engagement variable in the engaged category. career development does not affect nurse performance; Self-efficacy has a positive effect on employee engagement; Career development does not affect employee engagement. Research findings: nurse performance in the high category, self-efficacy in the high category, career development in the good category, and employee engagement variable in the engaged category. career development does not affect nurse performance; Self-efficacy has a positive effect on employee engagement; Career development does not affect employee engagement. Research findings: nurse performance in the high category, self-efficacy in the high category, career development in the good category, and employee engagement variable in the engaged category.
\end{abstract}

Keywords : $\quad$ Self Efficacy, Career Development, Employee Engagement, and Nurse Performance

\section{INTRODUCTION}

Human Resources (HR) is the key to the success of an organization is facing competition in the global era. Human resources are an integrated ability of thinking and physical power possessed by individuals (Bohlander \& Snell, 2010). These resources are built to be able to compete in the face of increasingly fierce competition. One of the factors for the success of human resource management in an organization is employee performance. Organizations can be said to be 
successful when the performance of the organization's employees is good. Performance as a result of individual or group activities in an organization is an important thing that shows the successful implementation of the management system. Human resources involved in health services in hospitals consist of multi professions, both health workers and non-health workers.

Human Resources in the most dominant hospital are nurses. Research in several hospitals states that $60-70 \%$ of human resources in the hospital are nurses (Gilles, 1994). Nurses are the most dominant personnel who provide services to patients for 24 hours continuously. Thus, nurses are health workers who are most often in direct contact with patients and families, so that their role greatly determines the quality of service in the hospital. The current performance of nurses can be seen from several aspects such as in providing services to patients which refers to the behavior, professional abilities, and nursing processes in achieving or maintaining optimal biological, psychological, social, and spiritual states.

Factors that can affect performance are employee engagement (Djani, 2015; Azizah \& Gustomo, 2015; Ardi et.al 2017; Nurfajar et.al 2018; Motyka, 2018). Engagement occurs when a person is consciously alert and emotionally connected with another person. When the employee is engaged, the employee has an awareness of the purpose of his role to provide services so that the employee will give his best. One way for employees to repay their organization's services is through their engagement, employees will choose to involve themselves in the various levels that individuals receive from their organization (Saks, 2006). Employees will show the behavior of accepting all situations that occur in the organization and contribute to the progress of the organization.

Nurses are also required to provide quality and satisfying services for patients, for that nurse must have certain behavioral dispositions to complete each given task. One of these behavioral dispositions is self-efficacy. Self-efficacy influences employee performance (Ming and Yen, 2012; Cherian \& Jacob, 2013; Salman et.al 2016; Rahayu et.al 2018). Self-efficacy refers to an individual's beliefs about his abilities, mobilizing the motivation, cognitive resources, and actions needed to successfully carry out a task in a particular context. High self-efficacy will develop a strong personality in a person, reduce stress, and are not easily affected by threatening situations

The performance of nurses in the hospital service business is supported by one of the factors, namely career development (Kakui and Gachunga, 2016; Nasution et.al 2018; Yunus et.al 2018). Career development is an important aspect that should not be overlooked in managing human resources (Sari \& Sinulingga, 2011). An employee who wants to develop his career needs to think about what performance appraisals he has. Employee career development should be seen as an investment not a cost and that poor performance and low commitment are costs in the organization (Pareek \& Rao, 2012).

Dharmais Cancer Hospital is a technical implementation unit of the Ministry of Health which is under and responsible to the Directorate General of Health. One of the main tasks of the Dharmais Cancer Hospital is to provide patient care and services according to the required modalities (such as surgery, chemotherapy, and radiation). Human resources, especially nurses at "Dharmais" Cancer Hospital, totaling 510 nurses consisting of Cancer Clinic Pre-Nurses (PrePKK), Cancer Clinic Nurses I (PKK I), Cancer Clinic Nurses II (PKK II), Cancer Clinic Nurses III (PKK III) and Cancer Clinic Nurse IV (PKK IV) with civil servant status, BLU and PKWT (Specific Time Work Agreement). Carrying out professional practice in outpatient, inpatient, and specialty care.

From the results of the nursing audit (assessment, nursing diagnosis, planning, implementation, and evaluation) by the Nursing Committee of the Dharmais Cancer Hospital which was carried out in 2019, the results obtained were Anggrek 1 98\%, Mawar 1 89\%, Anggrek 294\%, Mawar 2 100\%, Cempaka 94 \%, RIM 100\%, RIRA 100\%, Lotus 95\%, Tulip 100\%, Child 98\%, 
ICU $100 \%$, HCU 100\%, PICU 100\%, IGD 96\%, the data shows that in some rooms there are still results that are below $90 \%$ such as in the Mawar 1 room (documentation of nursing diagnoses only reached $78 \%$ with an average nursing care documentation of $89 \%$ ), then in the IGD room the assessment documentation reached $81.2 \%$, documentation of nursing diagnoses reached $87.5 \%$. It is hoped that the nursing documentation carried out can reach a value of $100 \%$ such as in the ICU, HCU, Tulip, RIM, PICU, and RIRA rooms.

From the nursing report, the turnover of nurses at the Dharmais Cancer Hospital is quite high. The data obtained from 2016-2019 is a turnover in 2016 with 27 nurses, 2017 with 34 nurses, 2018 with 18 nurses, and the highest in 2019, 42 nurses. In the last four years, the turnover of nurses has reached 121 people and in the January-May report 19 nurses left the Dharmais Cancer Hospital, they said that they left the hospital for several reasons, namely moving their work to another hospital such as a hospital. owned by the local government or other health institutions, did not extend the contract, there was no clarity on the rules and work status, resigned, was accepted by CPNS, and also family factors. One of the effects of turnover is less than optimal performance. This phenomenon shows that the sense of engagement with nurses is still low. Engagement is a characteristic of employees who are committed to the organization, therefore engaged employees have a strong dedication to the company so that they will work more productively in advancing the company (Nurfajar et.al 2018).

Based on the observations made by the researchers regarding the performance of nurses, self-efficacy is a factor that influences the success of the performance that nurses do, it can be seen from they do not see duties as a threat they must avoid, many nurses at Dharmais Cancer Hospital are members of the Functional Nursing Staff Group ( KSPF) such as Children KSPF, Chemotherapy KSPF, Wound Care KSPF, Palliative KSPF, Radiotherapy KSPF and so on. It appears that they develop a deep intrinsic interest and interest in an activity and develop goals to improve its performance.

Nurse data based on employment status and clinical nurse level at Dharmais Cancer Hospital, namely with 265 civil servant status, 145 BLUs, 100 PKWT and based on the clinical nurse career ladder, Pre PK totaled 87, PK I totaled 107, PK II amounted to 138, PK III totaled 167, PK IV totaled 11 with a total number of nurses, namely 510 people. This data shows that there are still many nurses who have the status of PKWT (Specific Time Work Agreement) or contract, which is 100 nurses, based on the career ladder, it shows that there is a Pre-PK clinical nurse level, at that level are nurses who are still in the orientation period or do not have a clinical assignment letter, Also obtained data on nurses with the PK IV level was only 11 people, very little compared to other clinical nurse levels.

Based on previous research by Ardi et.al (2017) entitled The Influence of Self Efficacy on Employee Engagement and Employee Performance (Studies on Employees of PT Telekomunikasi Indonesia Regional V Surabaya) show that there is an indirect effect (indirect effect) for selfefficacy on employee performance through Employee engagement, in line with research by Nurfajar et.al (2018), the results of the study show that simultaneously employee engagement, selfefficacy on employee performance has a significant positive effect, but partially self-efficacy has a negative effect. Other research by Setyabudi et.al (2018) shows that self-efficacy does not have a significant effect on nurse performance. The difference between this research and the research to be carried out is the addition of career development variables,

Low Employee Engagement causes the hospital to lose employees and of course, this automatically requires the hospital to replace new employees to meet the needs of service personnel. This is of course very detrimental because of having to recruit and orientate, which of course requires time and money. Losing employees will certainly interfere with the smooth running of service activities and the performance of other employees. So the question arises why the nurse 
turnover rate is high, is there a triggering factor such as self-efficacy originating from the employee who is the cause or other factors such as career development that employees feel or receive during work, Based on this explanation, the researcher is interested in conducting research entitled "The effect of self-efficacy and career development on employee engagement and the performance of nurses at Dharmais Cancer Hospital." The objectives of this study are: First, to determine and analyze the effect of Self Efficacy and Career Development on Employee Engagement and Nurse Performance at Dharmais Cancer Hospital; second, to study and analyze the effect of Employee Engagement on Nurse Performance; third, to study and analyze the effect of Self Efficacy on Nurse Performance; fourth, to examine and analyze the influence of Career Development on Nurse Performance; fifth, to study and analyze the effect of Self Efficacy on Employee Engagement; sixth,

\section{Hypothesis}

The hypotheses in this study are (1) Self Efficacy and Career Development has a simultaneous effect on Employee Engagement and Nurse Performance, (2) Employee Engagement has a positive effect on Nurse Performance, (3) Self Efficacy has a positive effect on Nurse Performance, (4) Career Development has a positive effect on Nurse Performance, (5) Self Efficacy has a positive effect on Employee Engagement. (6) Career development has a positive effect on Employee Engagement.

\section{RESEARCH METHODS}

\section{Samples and sampling techniques}

The research was conducted at the National Cancer Center "Dharmais" Cancer Hospital which is located on Jl. Let Jend S. Parman Kav.84-86, Slipi, Jakarta 11420. This research was conducted from April - September 2020. The design of this research is descriptive analysis with a model of causality or influence relationships. The sample in this study amounted to 200 respondents who used the Maximum Likelihood Estimation (MLE) estimation model. The sampling technique used in this study was Proportional Systimetic Sampling, to obtain 129 nurses of respondents with PNS employment status and 71 BLU staffing status. The inclusion criteria in this study are nurses who work at Dharmais Cancer Hospital with civil servant status and BLU, clinical nurse level PKK I - PKK IV, Performing Nursing Services, willing to be a respondent. The exclusion criteria in this study were nurses with PKWT employment status and nurses who no longer provided direct nursing services.

\section{Research Instrument}

The type of instrument used in this study was a questionnaire. Consisting of 48 statements with details as follows; Performance variable 18 statements (item no. 1-18), variable self-efficacy 6 statements (item no 19-24), career development variable 18 statements (item no 25-42), and variable employee engagement with 6 statements (item no 43-48). This study uses a Likert scale with 4 categories which aim to eliminate doubtful answers from respondents with criteria 1: Strongly Disagree; 2: Disagree; 3: Agree; 4: Strongly Agree.

\section{Validity and reliability of the instrument}

The validity test is done by comparing the results of the $r$ table with $r$ count, that is, if $r$ table $<\mathrm{r}$ count is said to be valid while $\mathrm{r}$ table> $\mathrm{r}$ count is said to be invalid. The pilot study was conducted at the Dharmais Cancer Hospital with a total sample of 30 nurses with a calculated rvalue of 0.361 (significance level 5\% $\mathrm{n}=30$ ). Nurse performance variables with 18 question items: 17 question items on nurse performance variables were declared valid, one item was invalid, 
namely KP2 items with $\mathrm{r}$ count 0.343 and declared invalid. The Self Efficacy variable with 6 question items was declared valid. The career development variable with 18 questions was declared valid. Employee engagement variable with 6 questions was declared valid.

In this study, researchers tested the reliability of the data using Cronbach Alpha. According to Hair et.al (2014), the size of the reliability coefficient is between 0 and 1 , with the minimum reliability coefficient being between 0.6 and 0.7. The test results obtained the Cronbach Alpha value of the nurse performance variable, namely 0.947 ; self-efficacy variable, namely 0.886 ; The career development variable is 0.977 and the employee engagement variable is 0.922 .

\section{Three Box Method}

The analysis of the answer index per variable aims to find a descriptive picture of the answers to the questions posed by the respondents. The scoring technique used in this study is a maximum score of 4 and a minimum of 1 with a total of 200 respondents. The average score (index) is categorized into score ranges based on the calculation of the three-box method (Ferdinand, 2006). Upper limit of the score range: $(\% \mathrm{~F} * 4) / 4=(200 * 4) / 4=200$; The lower limit of the score range: $(\% \mathrm{~F} * 1) / 4=(200 * 1) / 4=50$. Based on the calculation, the resulting score is between 50 200 with a range of 150 . The results of the range are divided into three (three-box method), namely equal to 50, resulting in the following distribution: index value of 50-100 in the low category; 101150 in the moderate category, and 151-200 in the high category.

\section{Data Analysis Techniques}

The analysis technique used to analyze the data is SEM (Structural Equation Model) analysis. According to Ghozali (2011), Structural Equation Modeling or structural equation modeling is a multivariate analysis technique used by researchers to test the relationship between complex variables both recursive and non-recursive to get a comprehensive picture of the entire model.

\section{Ethics Review}

This research protocol has gone through an ethical review process and passed an ethical review by the Research Ethics Commission of Esa Unggul University with a certificate Number: 0311-20.292 / DPKE-KEP / FINAL-EA / UEU / VIII / 2020 and the Ethics Committee for Research at the Dharmais Cancer Hospital. with a statement of passing the ethical review Number: 0148 / $\mathrm{KEPK} / \mathrm{X} / 2020$.

\section{Result}

\section{Characteristics of Respondents}

The majority of respondents were female nurses as many as 117 people $(58.5 \%)$ and the rest were men as many as 83 people (41.5\%). Respondents based on age were dominated by respondents aged 20-30 years as many as 83 people (41.5\%). Respondents based on education, most of the nurses have DIII Nursing education as many as 84 people (42\%) and S1 Nursing as many as 109 people $(54.5 \%)$. Respondents based on the highest career path were PK III nurses, namely 85 people (42.5\%). Respondents based on length of work, namely 1-5 years $73(36.5 \%)$ and a work period of more than 15 years as many as 63 people (31.5\%). Respondents based on employment status, as many as 129 people (64.5) were civil servants and as many as 71 (35.5) people with BLU employment status (Table 1) 
Table 1. Characteristics of Respondents

\begin{tabular}{|c|c|c|}
\hline Characteristics & amount & Percentage \\
\hline \multicolumn{3}{|l|}{ Gender } \\
\hline Man & 83 & 41.5 \\
\hline Women & 117 & 58.5 \\
\hline \multicolumn{3}{|l|}{ Age } \\
\hline 20-30 Years & 83 & 41.5 \\
\hline 31-40 Years & 53 & 26.5 \\
\hline $41-50$ years & 64 & 32 \\
\hline \multicolumn{3}{|l|}{ Education } \\
\hline DIII Nursing & 84 & 42 \\
\hline Nursing SI / NERS & 109 & 54.5 \\
\hline Master of Nursing & 6 & 3 \\
\hline S2 Health & 1 & 0.5 \\
\hline \multicolumn{3}{|l|}{ Career Path } \\
\hline Clinical Nurse 1 & 75 & 37.5 \\
\hline Clinical Nurse II & 31 & 15.5 \\
\hline Clinical Nurse III & 85 & 42.5 \\
\hline Clinical Nurse IV & 9 & 4.5 \\
\hline \multicolumn{3}{|l|}{ Years of service } \\
\hline $1-5$ Years & 73 & 36.5 \\
\hline 6-10 Years & 35 & 17.5 \\
\hline 11-15 Years & 29 & 14.5 \\
\hline More than 15 Years & 63 & 31.5 \\
\hline \multicolumn{3}{|l|}{ Employment status } \\
\hline Civil servants & 129 & 64.5 \\
\hline BLU & 71 & 35.5 \\
\hline
\end{tabular}

Source: Primary data processed, 2020

\section{Three Box Method Analysis}

Resume descriptions of respondents' answers about attitudes in behavior are shown in the behavior matrix shown in the following table: 
Table 2. Matrix of Respondents' Responses at Dharmais Cancer Hospital

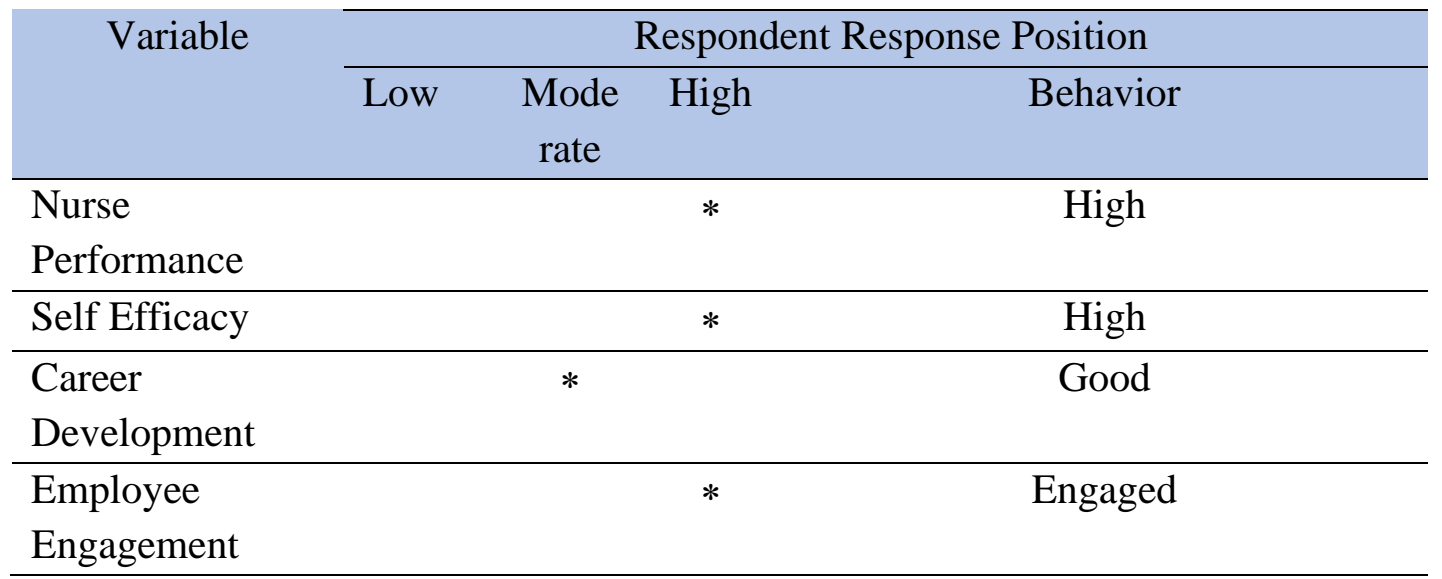

source: the results of the three-box method (2020)

Based on table 1, shows the response to nurse performance, self-efficacy, career development, and employee engagement of nurses at the Dharmais Cancer Hospital. The results showed that all variables had a positive overall response. Descriptive analysis using the three-box method variable performance of nurses in the high category, self-efficacy in the high category, career development in good categories, and variable employee engagement in the category engaged.

\section{Structural Model Analysis}

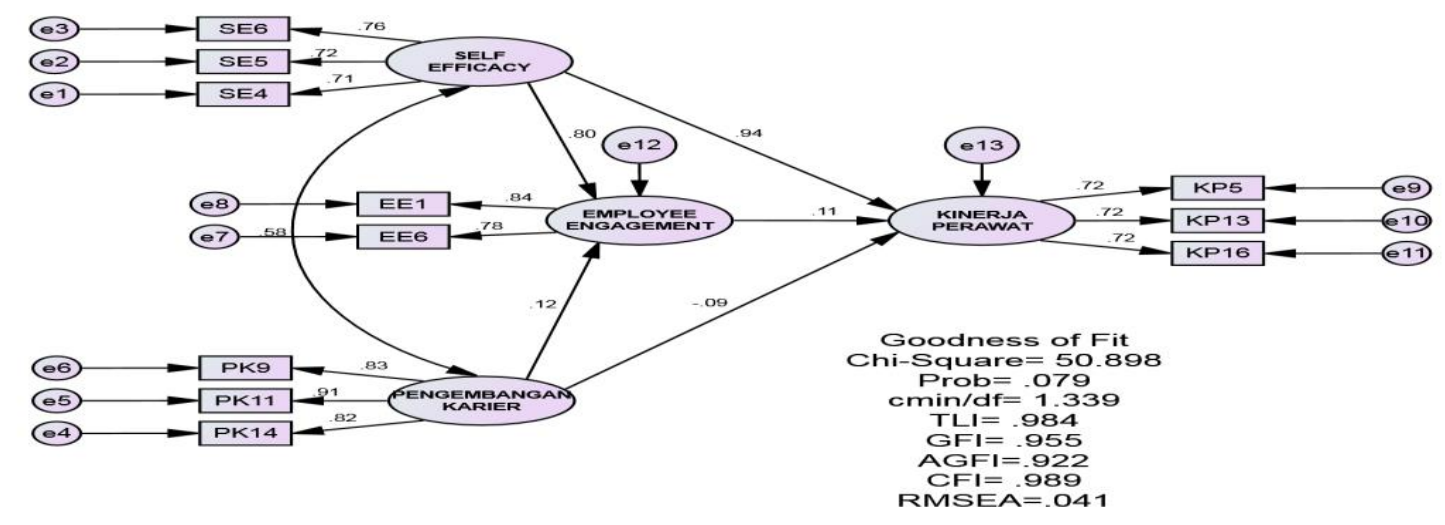

\section{Picture 1}

\section{Full Modification of the Final Model}

After modifying the model, the results presented in Figure 1 are a model that can be said to be a good fit because it has a value in the good fit category, namely the values of Chi-Square, RMSEA, CFI, and CMIN / DF. In the model that has been modified as many as 37 indicators are eliminated to get a fit model result and only 11 indicators are left, of course, this is still a model in the initial stage of testing whose results depend only on 200 respondents in this study alone, for further research with a sample that is different may have different results. 


\section{The goodness of Fit Test Results}

The Goodness of Fit test is carried out to see whether the model is a good fit or a poor fit. The test results can be seen in the following table:

Table 3

The goodness of Fit Test Results

\begin{tabular}{cccc} 
Goodness of fit & Cut - off Value & $\begin{array}{c}\text { Model } \\
\text { Results }\end{array}$ & Information \\
\hline X2 - Chi-Square & $\begin{array}{c}\text { It is expected that the } \\
\text { value is small with the } \\
\text { degree of freedom (DF) } \\
=38, \text { the table value } \\
53.38(0.05)\end{array}$ & 50,898 & Good Fit \\
& $\geq 0.05$ & 0.079 & Good Fit \\
\hline Probability & $\leq 2$ & 1,339 & Good Fit \\
\hline Cmin / DF & $\geq 0.90$ & 0.955 & Good Fit \\
\hline GFI & $\leq 0.079$ & 0.041 & Good Fit \\
\hline RMSEA & $\geq 0.90$ & 0.922 & Good Fit \\
\hline AGFI & $\geq 0.90$ & 0.984 & Good Fit \\
\hline TLI & $>0.90$ & 0.989 & Good Fit
\end{tabular}

Source: AMOS 24 data processing (2020)

Based on Figure 1, the full model analysis shows that the model meets the fit criteria. This can be explained by the value of the calculation results that meet the eligibility criteria for the full model SEM model in detail shown in Table 3. Based on Table 3, the results of the chi-square test calculation on the full model obtained a value of 50,898, which means that it meets the required requirements. This value is acceptable and can carry out further analysis by looking at the CMIN / DF, RMSEA, and CFI values that have met the good criteria, then further analysis can be carried out. Based on these results, it can be explained that the model in this study as a whole meets the criteria as a fit model.

\section{Partial Hypothesis Testing Results}

Hypothesis testing is carried out using the SEM program, namely the value of the Critical Ratio (cr) on the Regression Weight of the fit model. If the value of Critical Ratio (cr) $\geq 1.967$ or the probability value $(\mathrm{P}) \leq 0.05$ then Ho is rejected (the research hypothesis is accepted). The results of processing by AMOS on the full model can be seen in Table 3 as follows:

Table 4

Hypothesis Test of Direct Effect (Hypotheses 2-6)

\begin{tabular}{|c|c|c|c|c|c|}
\hline Hypothesis & Estimate & SE & CR & $\mathbf{P}$ & Information \\
\hline Employee Engagement $\rightarrow$ Nurse & .096 & .191 & .502 & .616 & $\mathrm{H} 2$ is \\
\hline Performance & & & & & rejected \\
\hline Self Efficacy $\rightarrow$ Nurse & .936 & .241 & 3,883 & $* * *$ & H3 accepted \\
\hline
\end{tabular}




\begin{tabular}{lccccl} 
Performance & & & & & \\
\hline $\begin{array}{l}\text { Career Development } \rightarrow \text { Nurse } \\
\text { Performance }\end{array}$ & -.060 & .050 & $-1,191$ & .234 & H4 rejected \\
\hline $\begin{array}{l}\text { Self Efficacy } \rightarrow \text { Employee } \\
\text { Engagement }\end{array}$ & .904 & .130 & 6,957 & $* * *$ & H5 is \\
\hline $\begin{array}{l}\text { Career Development } \\
\rightarrow \text { Employee Engagement }\end{array}$ & .089 & .061 & 1,450 & .147 & H6 rejected \\
\hline
\end{tabular}

Source: AMOS 24 data processing (2020)

P-value $=* * *$ (meaning the number is below 0.001, so this is significant at the 0.01 level of significance, which is certainly better than the 0.05 level)

Mediation Hypothesis Testing Results

\section{Table 5}

Indirect Hypothesis Test (Hypothesis 1)

\begin{tabular}{lcccc}
\multicolumn{1}{c}{$\begin{array}{c}\text { Relations Between } \\
\text { Constructs }\end{array}$} & $\begin{array}{c}\text { Mediation } \\
\text { Variables }\end{array}$ & $\begin{array}{c}\text { Direct } \\
\text { Effect }\end{array}$ & $\begin{array}{c}\text { Indirect } \\
\text { Effect }\end{array}$ & Information \\
\hline $\begin{array}{l}\text { Self Efficacy } \rightarrow \text { Nurse } \\
\text { Performance }\end{array}$ & $\begin{array}{c}\text { Employee } \\
\text { engagement }\end{array}$ & .942 & .087 & Not Mediating \\
\hline $\begin{array}{l}\text { Career Development } \\
\rightarrow \text { Nurse Performance }\end{array}$ & $\begin{array}{c}\text { Employee } \\
\text { engagement }\end{array}$ & -.094 & .013 & Not Mediating \\
\hline
\end{tabular}

Source: AMOS 24 data processing (2020)

\section{Discussion}

Hypothesis 1: the indirect hypothesis test results are shown in Table 4, the effect of selfefficacy on nurse performance through employee engagement is 0.087 or $8.7 \%$ (greater direct effect), whereas the influence of career development on nurse performance through employee engagement is 0.013 or $1.3 \%$ (greater indirect effect). This study states that the variable selfefficacy and career development simultaneously have not affected nurse performance mediated by employee engagement. Self-efficacy has a direct role in employee engagement, self-efficacy can encourage the willingness of employees to bond with the company, this is supported by research by Ardi et.al (2017); Rugiyanto (2017); Muliana and Rahmi (2019) state that self-efficacy has a positive direct effect on Employee Engagement. Self-efficacy has a big role in improving employee performance, either directly or mediated by employee engagement (Fajriah and Darokah, 2016). According to Hedger in Zulfa (2014) inSumadhinata and Murtisari (2017), One of the most effective ways to keep engaged employees is to show them that they are appreciated. There are many forms of appreciation, one of which is career development. Career development is very important for employees in a company. Career development can make employees more motivated to improve performance.

Hypothesis 2: the results of testing the direct effect of Employee Engagement on Nurse Performance show that the estimated value is 0.096 with a $C R$ of 0.502 ( $\mathrm{cr} \geq 1.967$ ) and a p-value of 0.616 ( $p$-value $<0.05$ ), meaning that the effect of employee engagement on nurse performance that is, $6.9 \%$ and $93.1 \%$ are other factors that were not examined in this study. The results of the analysis showed that there was no significant influence between employee engagement on nurse performance. Based on these results, it can be explained that higher employee engagement will not affect nurse performance. The results of this study are not in line with Ilyas and Nurtjahjanti (2015) who said employees who work with feelings that are engaged have the possibility of developing self-potential, experience with quality work that leads to individual productivity. Research by Gruman \& Saks (2010) states that employee engagement has a positive relationship in increasing 
more productive performance. This can create the performance of engaged employees so that they can make work more enjoyable and can improve their performance in the company. This automatically leads to an increase in the company's performance going forward. The results of this study are not in line with previous research by Ardi et.al 2017 which states that if employees are tied to the company at work it will have an impact on employee performance achievement will also increase. This is supported by previous research by Djani (2015); Azizah \& Gustomo (2015); Nurfajar et.al (2018) which states that there is a significant influence between employee engagement and employee performance. At the Dharmais Cancer Hospital, the assessment of work results is based on the assessment of individual performance indicators, the results of which become a reference in remuneration payments or salaries to be obtained by nurses. In the individual assessment indicators (IKI) there are targets both in quality and quantity that must be met so that in this study employee engagement does not affect performance.

Hypothesis 3: the results of testing the direct effect of Self Efficacy on nurse performance show that the estimated value is 0.936 with a CR of 3.883 ( $\mathrm{cr} \geq 1.967$ ) and a p-value of $* * *$ ( $\mathrm{p}$ value $<0.05$ ), meaning that self-efficacy affects. amounting to $93.6 \%$ of the performance of nurses and $6.4 \%$ of other factors. The results of the analysis show that there is a positive influence between self-efficacy on performance. This shows that the higher the self-efficacy of a nurse, the higher the performance. The results of this study are supported by previous research by Ardi, Astuti, and Sulistyo(2017) stated that self-efficacy can have a positive effect on employee performance. In this study, it was explained that the higher the self-efficacy of an employee, the employee will spend a lot of effort so that they can achieve high performance. The research suggests paying more attention and providing direction and guidance to employees to further increase self-confidence so that they can rely on themselves. This is supported by research by Kurra \& Aty (2015); Salman et.al (2016); Rahayu et.al (2018) which states that there is a significant influence between self-efficacy on employee performance. Self-efficacy that can affect the performance of nurses is Magnitude (level), Generality (breadth), Strength (strength). Nurses at Dharmais Cancer Hospital are members of the Functional Nursing Staff Group (KSPF) such as KSPF Children, KSPF Chemotherapy, KSPF Wound Care, Palliative KSPF, Radiotherapy KSPF, and so on. It appears that they develop a deep intrinsic interest and interest in an activity and develop goals to improve its performance.

Hypothesis 4: the results of testing the direct effect of Career Development on Nurse Performance show that the estimated value is -0.060 with a CR of -1.191 ( $\mathrm{cr} \geq 1.967$ ) and the pvalue of 0.234 (p-value <0.05) means that career development has an effect of $6 \%$ of the nurse's performance and $94 \%$ are other factors. The results of the analysis show that there is no significant influence between career development and nurse performance. Based on these results it can be explained that the higher the career development will not affect the performance of nurses. The results of this study are not in line with Robbins (2002) in Nasution et. al (2018) which shows that a person's performance is not only influenced by his internal factors such as motivation and abilities but also by the opportunity to develop his career provided by the organization for him because career development will trigger him to improve his abilities which will ultimately affect his performance. at work (Amstrong, 2001 in Nasution et.al 2018). Research by Nasution et.al (2018) states that career development has a positive and significant effect on employee performance, career development can make employees more motivated to improve performance. By carrying out employee career development, the quality will certainly increase. Saleem and Amin (2013) in Nasution et. al (2018) also show that employee performance increases along with better quality career development, which is a form of organizational support. This is in line with previous research conducted by Kakui and Gachunga (2016); Ali et.al (2016); Setyabudi et.al 2018, where the results of the study show that career development has a positive and significant impact on employee performance. The development of a professional nurse career path has been regulated in PMK No. 40 of 2017, where a nurse will go through a career path placement according to her competence, which is carried out through continuous professional development (formal education, 
training, workshops, etc.) and recognition of her abilities. which is based on work experience and performance of the nursing practice.

Hypothesis 5: the results of testing the direct effect of self-efficacy on employee engagement show that the estimated value is 0.904 with a $C R$ of 6.957 ( $\mathrm{cr} \geq 1.967)$ and a p-value of *** (p-value $<0.05$ ), meaning that self-efficacy affects. $90.4 \%$ of employee engagement and $9.6 \%$ are other factors. The results of the analysis showed that there was a positive influence on selfefficacy on employees. This shows that the higher the self-efficacy of a nurse, the more employee engagement will be increased. The results of this study are supported by previous research by Muliana and Rahmi (2019) which concluded that there is a positive direct effect of self-efficacy on work engagement. In this study, it is said that the level of self-efficacy or self-confidence that is owned by them will determine the success or lack of success in carrying out their work. It is further explained that if a person has high self-efficacy, then he will be confident and feel capable of carrying out his job, he will feel able to carry out his duties properly, goals that have been planned, can motivate himself and be able to overcome challenges, and they will have positive attitudes and behaviors, they will be connected physically, cognitively and emotionally, which are related to job fulfillment, in achieving the goals set by the institutional institution, they will feel engaged with their work, persistent and have strong dedication. high, have the initiative, In line with this research, Ardi et.al (2017) show that self-efficacy can have an impact on employees so that they want to be tied to the company, employees' confidence in their ability to do their best will make employees more attached to the company. His research found that self-efficacy was positively related to the level of goal setting. This is supported by the research of Rugiyanto (2017) which states that selfefficacy has a positive direct effect on Employee Engagement.

Hypothesis 6: the results of testing the direct effect of Career Development on employee engagement show that the estimated value is 0.089 with a CR of 1.450 ( $\mathrm{cr} \geq 1.967$ ) and a $\mathrm{p}$-value of 0.147 (p-value <0.05) means that career development has an effect of $8,9 \%$ of employee management and $91.1 \%$ are other factors. The results of the analysis show that there is no significant effect between career development on employee engagement. Based on these results, it can be explained that higher career development will not affect employee engagement. The results of this study are not in line with previous research conducted by Yolanda and Sari (2019) which concluded that career development has a significant and partial effect on Employee Engagement. In this study, it was explained that one of the effective ways to retain employees is to show that they are appreciated. One of them is by providing opportunities for employees to develop their careers. The research suggests that to optimize career development, among others, hold or improve training programs and the latest learning development for employees according to employee needs so that their knowledge and skills are expected to be following their work. Career development can increase employee engagement, Sumadhinata and Murtisari (2017) stated that career development had a significant effect on employee engagement. The employment status of respondents is PNS and BLU employees so that the employment status is permanent so that high nurse employee engagement and career development do not have a significant effect.

\section{Conclusion}

Based on data analysis and discussion of research results, it can be concluded as follows: (1) The variable of self-efficacy and career development indirectly mediated by employee engagement has not affected nurse performance, (2) The employee engagement variable has no effect on nurse performance. This means that other factors affect the performance of nurses. The nurse is in the 
engaged category but is not strong enough to improve the nurse's performance, (3) The self-efficacy variable has a positive effect on the nurse's performance. This means that the higher the selfefficacy of a nurse, the higher the performance produced, (4) Career development variables do not affect nurse performance. The career development felt by nurses is in a good category, but not yet strong in improving the performance of nurses, (5) the variable self-efficacy has a positive effect on employee engagement. This means that the higher the self-efficacy that is owned, it will increase employee engagement or the nurses will be more engaged, (6) Career development variables have no effect on employee engagement. Career development is in a good category but is not strong enough to increase nurse engagement.

The results of this study found that the importance of self-efficacy in nurses because the high self-efficacy of nurses resulted in high employee engagement and performance of nurses. To be able to achieve an advancement in the career ladder of nurses, of course, nurses must prepare the needs or conditions that are used in the process of advancing the career path through credentials, be it education, work experience, logbooks, and certificates from the training that is followed, and always improve knowledge and skills. in doing nursing care. The team leader, room head, or nursing manager has an important role in building nurse self-efficacy, which can be done by providing information about the self-efficacy of nurses, individuals who have high self-efficacy, if they get positive information about themselves, while individuals will have low self-efficacy if he gets negative information about himself. Maintain and continuously improve their performance, constantly update their knowledge through seminars, workshops, and training, and they must also be more active in advancing the clinical nurse level if they meet the specified requirements.

For research development, it is suggested that future research can add other variables that can affect employee engagement and performance of nurses and expand the study of the indicators of each variable through theory development efforts.

\section{REFERENCES}

Ardi, V, T, P, Astuti, E, S and Sulistyo, M, C, W. (2017). The Influence of Self-Efficacy on Employee Engagement and Employee Performance (Study on Employees of PT Telekomunikasi Indonesia Regional V Surabaya). Journal of Business Administration (JAB) | Vol. 52 No. November 1, 2017

Azizah, A and Gustomo, A. (2015). The Influence Of Employee Engagement To Employee Performance at PT Telkom Bandung. Journal Of Business And Management Vol. 4, No.7, 2015: 817-829

Bohlander, George., And Snell, Scott. (2010). Principles of Human Resource. Management, 15th ed. Mason, OH: South-Western - Cengage Learning

Cherian, J, and Jacob, J. (2013). Impact of Self-Efficacy on Motivation and Performance of Employees.International Journal of Business and Management; Vol. 8, No. 14

Dajani, M, A, Z. (2015). The Impact of Employee Engagement on Job Performance and Organizational Commitment in the Egyptian Banking Sector. Journal of Business and Management Sciences, 2015, Vol. 3, No. 5, 138-147

Giles. (1994). Management A system Approach, edition 3.WB. Saunders Company.

Hughes and Rog. (2008). Talent Management, A Strategy for Improving Employee Recruitment, Retention, and Engagement within Hospitality Organization. International Journal of Contemporary Hospitality Management.

Kakui, IM, and Gachunga, H. (2016). Effects of Career Development on Employee Performance in The Public Sector: A Case of National Cereals And Produce Board. The Strategic Journal of Business \& Change Management, Volume 3, Issue 3, Article 19, 308-324 
Ming, C, L, and Yen, C, C. (2012). Self-Efficacy, Effort, Job Performance, Job Satisfaction, and Turnover Intention: The Effect of Personal Characteristics on Organization Performance. International Journal of Innovation, Management and Technology, Vol. 3, No. 4, August 2012

Motyka, B. 2018. Employee engagement and performance: a systematic literature review. International Journal of Management and Economics 2018; 54 (3): 227-244

Nasution, FN, Mariatin, E., and Zahreni, S. (2018). The Influence of Career Development and Organizational Culture on Employee Performance. International Journal of Scientific Research and Management (IJSRM), Volume 06, Issue 01, January 2018, 57-65.

Nurfajar, Marzuqi, M, S. and Rohmayati, N. (2018). The Influence of Employee Engagement and Self-Efficacy on Employee Performance of PT Nikomas Gemilang PCI S5 Division Serang Banten. Journal of Entrepreneurial Development Vol. 20 NO. 01 - April 2018

Rahayu, M, Rasid, F and Tannady, H. (2018).Effects Of Self Efficacy, Job Satisfaction, And Work Culture Toward Performance Of Telemarketing Staff In Banking Sector. Southeast Asia Journal of Contemporary Business, Economics, and Law, Vol. 16

Salman, M, Khan, M, N, Draz, U, Iqbal, M, J, and Aslam, K. (2016). Impact of Self-Efficacy on Employee's Job Performance in Health Sector of Pakistan. American Journal of Business and SocietyVol. 1, No. 3, 2016, pp. 136-142

Sari, E., And Sinulangga, J. (2011). Effect of Career Development and Compensation on Employee Motivation. Scientific Journal of Managerial Management Research, 2 (1): 431-440

Schaufeli, WB, \& Bakker, AB (2004). Job demands, job resources, and their relationship with burnout and engagement: A multi-sample study. Journal of Organizational Behavior, 25, 293-315.

Setiawan, AP, T. Andjarwati. (2017) Influence of Self-Efficacy and Motivation on Employee Performance of PT. Busson Auto Finance (BAF) Surabaya Branch I. Journal of Management Economics, Pages 275 - 284275 Volume 2, Number 1, May 2017.

Setyabudi, MA, Musadieq, MA, and Aziz, A, L. (2018). The Influence of Career Development and Self-Efficacy on Employee Performance (Study of Nurse at Dr. Mohamad Saleh Probolinggo Hospital). Journal of Business Administration (JAB) | Vol. 63 No. 1

Sinambela, LP (2016). Human Resource Management, Jakarta: Earth Literacy.

Yunus, A, NM, T, Hamid, N and Yusuf, R, M. (2018). Leadership and Career Development on Organizational Commitment and Its Impact on Employee Performance of PT. Bank Mandiri (Persero) Tbk Makassar Kartini Area. Hasanuddin Journal of Applied Business and Entrepreneurship HJABE Vol. 1 No. April 2, 2018 